\title{
Composite Vessel Graft
}

National Cancer Institute

\section{Source}

National Cancer Institute. Composite Vessel Graft. NCI Thesaurus. Code C117821.

A vessel graft comprised of two or more conduit materials. 